\title{
The Role of Glyphosate in RR Soybean Production and Seed QUALITY ${ }^{1}$
}

\author{
Glyphosate na Produção e Qualidade das Sementes de Soja RR
}

\author{
ALBRECHT, L.P. ${ }^{2}$, ALBRECHT, A.J.P. ${ }^{3}$, BRACCINI, A.L. ${ }^{4}$, OLIVEIRA JR., R.S. ${ }^{4}$, ZOBIOLE, L.H.S. ${ }^{5}$, \\ and ÁVILA, M.R. ${ }^{6}$
}

\begin{abstract}
This study aimed to evaluate the production components and quality of RR soybean seeds (Roundup Ready ${ }^{\circledR}$ ), after application of increasing rates of gliphosate. Field experiments were conducted in Mandaguari, Paraná, during two seasons. Treatments consisted of five doses of glyphosate. All applications were performed once, between development stages $\mathrm{V}_{4}$ and $\mathrm{V}_{5}$. The experiment was arranged in a completely randomized block design, with four replicates. Data were subjected to analysis of variance, and when significant, t-tests and a regression analysis were applied to verify the behavior of the treatments. The physiological and sanitary quality, yield and mass of one thousand seeds were evaluated. The results indicated that seed quality can be adversely affected by glyphosate, and also showed a probable reduction in yield components with increasing rates of application.
\end{abstract}

Keywords: Glycine max, herbicide, transgenic.

\begin{abstract}
RESUMO - O presente trabalho teve como objetivo avaliar os componentes de produção e a qualidade das sementes de soja RR, em função da aplicação de doses crescentes de glyphosate. Os experimentos foram instalados em campo, no municipio de Mandaguari, Paraná, durante as safras 2006/2007 e 2007/2008. Os tratamentos foram compostos por cinco doses de glyphosate. Todas as aplicações foram realizadas em modalidade única entre o estádio $V_{4}$ e $V_{5}$ O delineamento experimental utilizado foi em blocos casualizados com quatro repetições. Os dados foram submetidos à análise de variância e; quando significativos, aplicou-se o teste te análise de regressão aos tratamentos. Foram avaliadas a qualidade fisiológica e sanitária das sementes, a produtividade e a massa de mil sementes. Os resultados indicam que a qualidade das sementes pode ser afetada negativamente pelo glyphosate e, também, demonstram provável redução nos componentes de produtividade com incrementos na dose.
\end{abstract}

Palavras-chave: Glycinemax, herbicida, transgênico.

\section{INTRODUCTION}

The herbicide glyphosate is widely used in agriculture, especially in genetically modified crops, but this herbicide may have some stressor effects, even on RR soybean plants (Roundup Ready ${ }^{\mathbb{}}$ ), for which it should be selective.
The RR soybean has an EPSPs enzyme from Agrobacterium sp., which is resistant to glyphosate. Nevertheless, glyphosate can have harmful effects on soybean crop yields and on the quality of the seeds produced (Albrecht \& Ávila, 2010). Glyphosate can produce phytotoxic effects and may affect the efficiency of water use, photosynthesis and nutrient balance in

Recebido para publicação em 6.6.2013 e aprovado em 17.9.2013.

2 Universidade Federal do Paraná, Palotina-PR, Brasil, <lpalbrecht@yahoo.com.br>; ${ }^{3}$ Universidade de São Paulo - Escola Superior de Agricultura “Luiz de Queiroz"Piracicaba-SP, Brasil; ${ }^{4}$ Universidade Estadual de Maringá, Maringá-PR, Brasil; ${ }^{5}$ CropProtection R\&D, São Paulo-SP, Brasil; ${ }^{6}$ Instituto Agronômico do Paraná, Londrina-PR, Brasil. 
soybeans (Zobiole et al., 2010a,b,c; Albrecht \& Ávila, 2010). Regardless of the stresses being imparted, these can lead to negative effects on the normal growth and development of plant species.(Taiz\&Zeiger, 2009).

Several studies have demonstrated that the use of glyphosate might cause problems in secondary metabolism (Lydon\& Duke, 1989; Zobiole et al., 2010c), in AIA (indole-3-acetic) metabolism (Lee, 1982), in the production of phytoalexins (Keen et al., 1982), in the rhizosphere (Kremer et al., 2005), in biological nitrogen fixation (Zablotowicz\& Reddy, 2004; Santos et al., 2004; Zobiole et al., 2010a), in mineral nutrition (Neumann et al., 2006; Zobiole et al., 2010a,d), in chlorophyll content (Zobiole et al., 2010c; Reddy et al., 2004), in photosynthesis (Zobiole et al., 2010b,c), in the absorption and use of water (Zobiole et al., $2010 \mathrm{~b})$, in the production and accumulation of biomass (Zobiole et al., 2010b), in amino acid and lignin content (Zobiole et al., 2010c) and in the production of metabolites with the potential for injury (Reddy et al., 2004).

However, the results of using glyphosate, applied alone or combined with other herbicides, still lack comprehensive information about their effects on the components of yield and seed quality and on their physiological and biochemical causes, making it necessary to search for information on identifying the actual limits and implications of using glyphosate on RR soybeans. The objectives of this study were to assess the components of yield and the physiological quality of RR soybean seeds after the use of increasing rates of glyphosate applied after emergence.

\section{MATERIALS AND METHODS}

The field experiment was performed in an experimental area within a rural property in the municipality of Mandaguari, in the northwestern State of Paraná, at $5^{\circ} 47^{\prime} \mathrm{W}$ and $23^{\circ} 29^{\prime} \mathrm{S}$, with a mean altitude of 640 meters. The predominant climate is $\mathrm{Cfa}$, according to the Köppen classification: a mesothermal humid climate with a rainy and hot summer and a dry winter. The soil in the experimental area was classified as a RhodicEutrudox, i.e., very clayey and located on a flat terrain.
The oat straw seeded in the winter was tilled in and desiccated with the herbicide glyphosate, which is commercially formulated as isopropylamine salt (360 g a.e. $\left.\mathrm{L}^{-1}\right)$, at a rate of $5 \mathrm{~L} \mathrm{ha}^{-1}$, thirty days before sowing the soybeans. The fertilization and cultivation practices, including pest and diseases management, were the same as those typically used in the production system in the region (Embrapa, 2006).

The soybean cultivar used was CD 214 RR, belonging to an early ripening group with a mean cycle of 115 days. The soybean seeding occurred on December 1, 2006 (experiment conducted on crop I), and November 30, 2007 (experiment conducted on crop II), with a $0.45 \mathrm{~m}$ spacing between rows, at a depth of approximately three centimeters and a density of 16 plants per linear meter. The plots consisted of six rows, each of which was six meters in length. The assessments used an area of $3.6 \mathrm{~m}^{2}$, including only the two central rows.

Treatments consisted of different rates of glyphosate application $(0,360,720,1,080$ and 1,440 g a.e. ha $^{-1}$ ) applied once between the $V_{4}$ and $V_{5}$ stages, i.e., on the $25^{\text {th }}$ day after the emergence of crop I and on the $23^{\text {th }}$ day for crop II. A constant pressure $\mathrm{CO}_{2}$ backpack sprayer equipped with XR-110.02 tips was used, using a pressure of $2.0 \mathrm{kgf} \mathrm{cm}^{-2}$ and a spray volume equivalent to $200 \mathrm{~L} \mathrm{ha}^{-1}$. The climatic conditions at the time of application were as follows: for crop I (2006), $28{ }^{\circ} \mathrm{C}$ (average air temperature) and 65\% relative humidity at 09:30 h; and for crop II (2007), $29{ }^{\circ} \mathrm{C}$ (average air temperature) and 63\% relative humidity at 09:20 h.

The seed yield in the plots was evaluated $\left(\mathrm{kg} \mathrm{ha}^{-1}\right)$ and the weight of a thousand seeds was determined (Brasil, 2009). To calculate the yield and weight of one thousand seeds, the moisture content of the seeds, determined by the oven method at $105 \pm 3{ }^{\circ} \mathrm{C}$ (Brasil, 2009), was corrected to a $13 \%$ wet basis.

The physiological quality of the seeds was evaluated by germination tests and by the first count of the germination test (indicative of vigor) (Brasil, 2009). The sanitary quality was evaluated using the filter paper method or a blotter test (Henning, 1994). 
The germination test was performed with four subsamples of 50 seeds for each treatment and field repetition. Seeds were sown between three sheets of paper toweling that had been moistened with distilled water, using an amount of water equivalent to three times the weight of the dry paper. The paper was formed into rolls and placed in a Mangelsdorf germinator, which was adjusted to a constant temperature of $25{ }^{\circ} \mathrm{C}$ for eight days. The results were expressed as the percentage of normal seedlings, according to the Rules for Seed Analysis (Brasil, 2009). The first count of the germination test was conducted along with the previous test by computing the percentage of normal seedlings obtained on the fifth day after sowing (Brasil, 2009).

The sanitary test was performed using the filter paper method with 100 seeds divided into five subsamples of 20 seeds for each field repetition. These seeds were placed on four sheets of filter paper in plastic boxes (gerbox), sterilized and moistened with distilled water and autoclaved. The incubation was undertaken under laboratory environmental conditions at a temperature of approximately $25^{\circ} \mathrm{C}$ under a $12: 12 \mathrm{~h}$ light:dark cycle using fluorescent lamps for seven days. After this period, we evaluated the level of fungi on the seeds using a magnifying glass with light and a stereoscopic microscope (Henning, 1994). The percentage both of total fungi and of each pathogenic species individually was evaluated.

The experimental design used completely randomized blocks with four repetitions. Data from each crop were subjected to an analysis of variance, and when the $F$ values were significant $(\mathrm{p}<0.05)$, a t-test and regression analysis were applied. The assumptions of the analysis of variance were met, and thus, the data were not transformed. For choosing the best regression model, the following criteria were adopted: significant regression, non-significant deviations in the regression, coefficient of determination, residue analysis and biological explanation.

\section{RESULTS AND DISCUSSION}

The results for the 2006/2007 crop are listed in Table 1 . The productivity, weight of 1,000 seeds (yield components) and characteristics relevant to the performance of seeds (physiological and sanitary quality) showed no significant responses $(p<0.05)$, except for sanitary quality. It was possible to adjust only one regression model for the occurrence of Cercospora kikuchii, according to the rates of glyphosate application (Figure 1). Using this method, the percentages of occurrence for each species of phytopathogenic fungus are presented in Table 2.

The significance observed in Figure 2, in which a positive linear response was verified with increasing rates of glyphosate, only allowed for the inference of an increasing effect on the occurrence of the fungus identified as Cercospora kikuchii, with an increase of $0.0067 \%$ in the incidence of fungi for every g a.e. ha- ${ }^{-1}$.

Table 1 - Response variables evaluated in seeds of the soybean cultivar CD 214 RR, produced under the effects of the post-emergence application of glyphosate in Mandaguari, State of Paraná, 2006/2007 crop

\begin{tabular}{|c|c|c|c|c|c|}
\hline \multirow{2}{*}{$\begin{array}{l}\text { Glyphosate } \\
\left(\mathrm{g}^{-} \text {a.e. } \mathrm{ha}^{-1}\right)\end{array}$} & \multicolumn{5}{|c|}{ Variables $-2006 / 2007$ Crop } \\
\hline & $\begin{array}{l}\text { Productivity } \\
\mathrm{kg} \mathrm{ha}^{-1}\end{array}$ & $\begin{array}{l}\text { Weight of one } \\
\text { thousand seeds g }\end{array}$ & $\begin{array}{l}\text { Viability } \\
(\%)^{\frac{1}{}}\end{array}$ & $\begin{array}{l}\text { Vigor } \\
(\%)^{1 /}\end{array}$ & $\begin{array}{c}\text { Sanitary Quality } \\
(\%)^{\frac{2 /}{}}\end{array}$ \\
\hline 0 & 2768.15 & 111.39 & 76.50 & 70.10 & 65.75 \\
\hline 360 & 3136.10 & 110.53 & 80.25 & 72.75 & 33.75 \\
\hline 720 & 3046.07 & 115.62 & 82.75 & 78.00 & 56.25 \\
\hline 1080 & 2792.92 & 112.56 & 81.10 & 76.00 & 48.50 \\
\hline 1440 & 2918.24 & 113.60 & 81.80 & 76.17 & 36.75 \\
\hline Average & 2932.31 & 112.74 & 80.48 & 74.27 & 48.20 \\
\hline $\mathrm{CV}(\%)$ & 20.71 & 2.75 & 4.41 & 4.79 & 24.60 \\
\hline$P^{3 /}$ & 0.89 & 0.23 & 0.15 & 0.06 & 0.01 \\
\hline
\end{tabular}




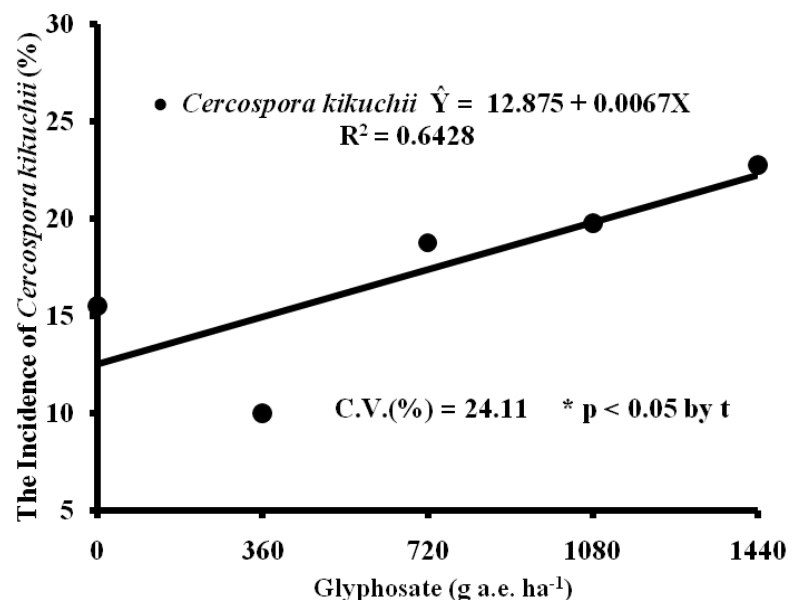

Figure 1 - Polynomial regression for the occurrence of the fungus Cercosporakikuchii in seeds of the soybean cultivar CD 214 RR, produced under the effects of the postemergence application of glyphosate in Mandaguari, State of Paraná, 2006/2007 crop.

The increased occurrence of Cercospora kikuchii was most likely due to the lower tolerance to pathogens found with increased rates of glyphosate application. This herbicide may affect the availability of certain micronutrients and increase the incidence of diseases (Johal\& Huber, 2009).

Because the fungus Cercospora kikuchiiis the etiological agent of leaf blight, a disease of the final cycle, and of purple seed stain, an increase in its occurrence at the expense of the sanitary quality of seeds may also reduce productivity. This claim is especially valid in years with climatic conditions that are more favorable to the proliferation of this fungus because it can affect the filling of soybean seeds.

Table 3 lists the results from the 2007/ 2008 crop, which show that the yield components were significantly affected with increasing rates of glyphosate, but only at a probability above $15 \%$. With regards to the quality of seeds, significant effects were detected at $15 \%, 3 \%$ or below $1 \%$, depending on the response variable examined. These findings indicated the responses for increasing rates of glyphosate applied to the crop, as furtherdetailed below.

For this last crop $(2007 / 2008)$, no significant results $(\mathrm{p}<0.05)$ were recorded for the incidence of Cercospora kikuchii, due to the different climatic characteristics in this year compared with the previous year, in which low rainfall had occurred near the physiological maturity of the $2007 / 2008$ crop. In this way, the average percentage of total fungi in the $2006 / 2007$ crop (48.20\%) was higher than that observed in 2007/2008 (22.45\%). However, both of the averages for incidence for this species, as for the others detailed in the sanitary quality test, are presented in Table 4.

With regards to seed performance, linear regression models were fitted for the vigor of seeds and for total fungi (Figures 2 and 3, respectively). In other words, with the increase in glyphosate rate, there was a negative linear response in vigor, with a reduction of $0.0049 \%$ for normal seedlings in the first count of the germination test for every g a.e. ha ${ }^{-1}$, and a positive response for the total fungi on soybean seeds with an increment of $0.7718 \%$ in the incidence of fungi for every g a.e. $\mathrm{ha}^{-1}$. This information denotes that increasing the glyphosate rate for this crop decreased both the physiological and sanitary quality levels.

The soil and climatic conditions for both experiments have not reached the commercial

Table 2 - Fungi isolated in the evaluation of sanitary for seeds of the soybean cultivar CD 214 RR, produced under the effects of the post-emergence application of glyphosate in Mandaguari, State of Paraná, 2006/2007 crop

\begin{tabular}{|c|c|c|c|c|}
\hline \multirow{2}{*}{$\begin{array}{c}\text { Glyphosate } \\
\left(\mathrm{g} \text { a.e. } \text { ha }^{-1}\right)\end{array}$} & \multicolumn{4}{|c|}{ Fungi isolated (\%) - crop 2006/2007 } \\
\cline { 2 - 5 } & Aspergillus spp. & Fusarium semitectum & Phomopsis spp. & Total \\
\hline 0 & 16.50 & 13.00 & 21.00 & 65.75 \\
\hline 360 & 4.50 & 7.75 & 11.50 & 33.75 \\
\hline 720 & 7.00 & 13.75 & 16.75 & 56.25 \\
\hline 1080 & 8.75 & 5.00 & 15.00 & 48.5 \\
\hline 1440 & 2.75 & 4.25 & 6.25 & 36.75 \\
\hline
\end{tabular}


Table 3 - Response variables evaluated in seeds of the soybean cultivar CD 214 RR, produced under the effects of the postemergence application of glyphosate in Mandaguari, State of Paraná, 2007/2008 crop

\begin{tabular}{|c|c|c|c|c|}
\hline \multirow{2}{*}{$\begin{array}{l}\text { Glyphosate } \\
\left.\left(\text { g a.e. }^{-1}\right)^{-1}\right)\end{array}$} & \multicolumn{4}{|c|}{ Variables $-2007 / 2008$ Crop } \\
\hline & $\begin{array}{l}\text { Productivity } \\
\mathrm{kg} \mathrm{ha}^{-1}\end{array}$ & $\begin{array}{l}\text { Weight of one } \\
\text { thousand seeds } g\end{array}$ & $\begin{array}{l}\text { Viability } \\
(\%)^{\frac{1}{1}}\end{array}$ & $\begin{array}{c}\text { Sanitary Quality } \\
(\%)^{\underline{2} /}\end{array}$ \\
\hline 0 & 3276.38 & 112.50 & 83.25 & 17.25 \\
\hline 360 & 3303.88 & 117.50 & 83.25 & 17.25 \\
\hline 720 & 3273.17 & 115.00 & 77.00 & 25.75 \\
\hline 1080 & 3328.13 & 117.50 & 80.00 & 22.50 \\
\hline 1440 & 2969.29 & 110.00 & 75.25 & 29.50 \\
\hline Average & 3230.17 & 114.50 & 79.75 & 22.45 \\
\hline CV $(\%)$ & 7.71 & 4.07 & 6.46 & 12.23 \\
\hline$P^{3 /}$ & 0.28 & 0.15 & 0.15 & 0.01 \\
\hline
\end{tabular}

$1 /$ Percentage of normal seedlings; $\stackrel{2}{2}$ percentage of total fungi; $\stackrel{3}{2}$ minimum probability that was significant.

Table 4 - Fungi isolated in the evaluation of sanitary of seeds of the soybean cultivar CD 214 RR, produced under the effects of the post-emergence application of glyphosate in Mandaguari, State of Paraná, 2007/2008 crop

\begin{tabular}{|c|c|c|c|c|}
\hline \multirow{2}{*}{$\begin{array}{c}\text { Glyphosate } \\
\left(\mathrm{g} \text { a.e. } \mathrm{ha}^{-1}\right)\end{array}$} & \multicolumn{4}{|c|}{ Fungi isolated (\%) -2007/2008 Crop } \\
\cline { 2 - 5 } & Aspergillus spp. & Cercospora kikuchii & Fusarium semitectum & Phomopsis spp. \\
\hline 0 & 1.50 & 9.00 & 1.75 & 5.00 \\
\hline 360 & 2.00 & 10.25 & 1.50 & 3.50 \\
\hline 720 & 2.25 & 13.00 & 2.75 & 7.75 \\
\hline 1080 & 2.00 & 12.75 & 1.25 & 6.50 \\
\hline 1440 & 6.00 & 12.00 & 2.75 & 8.75 \\
\hline
\end{tabular}

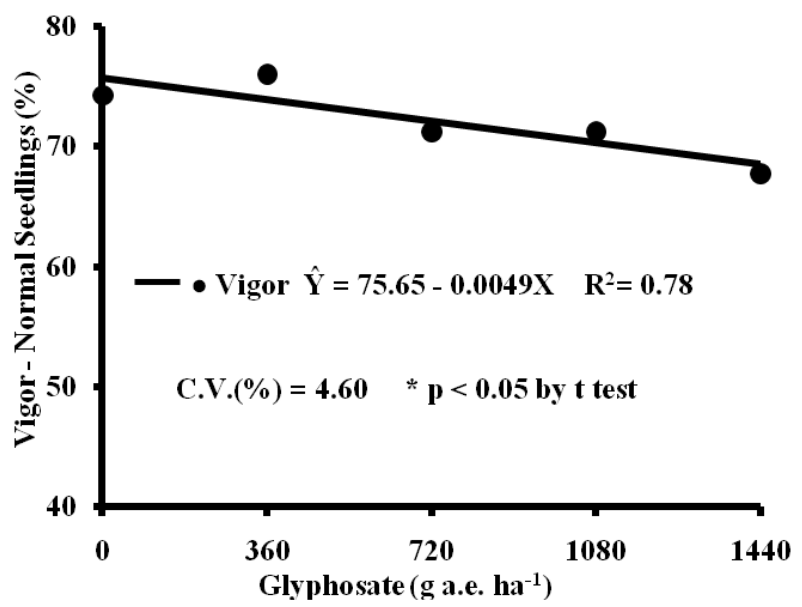

Figure 2 - Polynomial regression for the percentage of normal seedlings in the first count of the germination test (vigor) of seeds of the soybean cultivar CD 214 RR, produced under the effects of the post-emergence application of glyphosate in Mandaguari, State of Paraná, 2007/2008 crop.

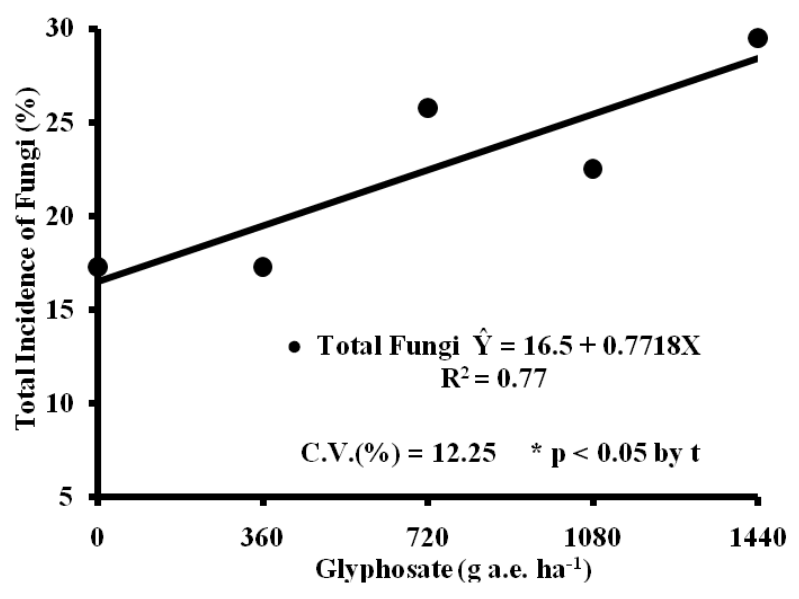

Figure 3 - Polynomial regression for the occurrence of fungi in seeds of the soybean cultivar CD 214 RR, produced under the effects of the post-emergence application of glyphosate in Mandaguari, State of Paraná, crop 2007/2008. 
standard for seeds for either multiplication or commercialization. They have, however, reached the standards for genetics and basic seed(Brasil, 2005).

The results indicate that there is potential for damage by glyphosate, corroborating the results discussed by Albrecht \& Ávila (2010), which are most likely related to or arise from potential injuries or the deleterious action of glyphosate, as found in the literature (Reddy et al., 2004; Huber., 2007; Santos et al., 2007; Zobiole et al., 2010a,b,c,d; Albrecht et al., 2011b; Albrecht et al., 2012a,b). Thus, changes in the nutritional balance and physiology of the plant as a whole, as well as in photosynthesis and other biosynthetic processes, can lead to decreased biomass accumulation in the tissues of agronomic interest, with potential negative effects in not only plant development but also the productivity and quality of seed harvested.

Plants with nutritional problems or with deficits in biomass accumulation are prone to having malformed seeds, implying the existence of physiologically less capable seeds (Marcos Filho, 2005). Plants with nutritional problems tend to have problems with metabolism, which damages the physiological apparatus and, consequently, seed quality. Mn, for example, acts as a cofactor, activating approximately 35 different enzymes and controlling the biosynthesis of aromatic amino acids and their secondary products, such as lignin and flavonoids (Taiz\&Zeiger, 2009). Flavonoids act in the root extracts of legumes by stimulating the expression of the nodulation gene. Low levels of lignin and flavonoids are also responsible for reductions in resistance to diseases (Rizzardi et al., 2003). Recently, Zobiole et al. (2010c) reported decreases in the lignin content of RR soybean plants at rates of 450 g a.e. ha ${ }^{-1}$.

Some authors have observed that substances with phytoalexinic actions on soybeans, such as glyceollin, have diminished antimicrobial action even at extremely low and non-toxic levels of glyphosate, caused by inhibition in the synthesis of these phytoalexins (Keen et al., 1982). This observation highlights the favorable situation for the proliferation of phytopathological agents.
Additionally, it is apparent that RR soybean plants contained residues of AMPA (aminomethylphosphonic acid), a product of glyphosate degradation, after the product had been applied (Arregui et al., 2003; Reddy et al., 2004).Although this herbicide is usually barely metabolized by plants, AMPA is found as the main metabolite in RR soybean seeds treated with glyphosate (Duke et al., 2003). However, only damage (reductions in chlorophyll levels and plant growth) has been proven to be caused by the degradation of glyphosate into AMPA. Increases in the glyphosate rate can elevate the AMPA content, thus enhancing the phytotoxic effects of this metabolite (Reddy et al., 2004). AMPA is accumulated in seeds (Duke et al., 2003), and its presence in soybean seeds can be harmful to their physiological potential, triggering disorders that lead to the formation of abnormal seedlings. According to Hoagland (1980), the AMPA activity is apparently different from that of the glyphosate, being less active, but can be toxic and can thus cause changes in soybean seedlings.

Based on the results and the assumptions raised, there is a trend for soybean seed quality to be negatively affected by the application of glyphosate at high rates. There is also the potential that increases in glyphosate rates at certain stages of development will affect the yield components. Nevertheless, further studies are necessary using different genotypes and different sowing times in distinct regions, with a higher number of applications at several stages, so a technical and scientific position on the issue can be consolidated.

\section{ACKNOWLEDGEMENTS}

We thank the farmer Alfredo Albrecht for collaboration and support during the execution of this study, which was performed on a rural property under his care. His help was essential for developing this study.

\section{LITERATURE CITED}

ALBRECHT, L. P.; ÁVILA, M. R. Manejo de glyphosateem soja RR e a qualidade das sementes. Inf. Abrates, v. 20, n. 2, p. 45-54, 2010.

ALBRECHT, L. P. et al.Qualidade fisiológica das sementes de soja RR em resposta ao uso de diferentes tratamentos contendo glyphosate em aplicação sequencial. Biosci. J., v. 27, n. 2, p. 211-220, 2011a. 
ALBRECHT, L. P. et al. Desempenho da soja RR sobaplicação de glyphosateem diferentes estádios. Planta Daninha, v. 29, n. 3, p. 585-590, 2011 b.

ALBRECHT, L. P. et al.Glyphosate e associaçõesempósemergência no desempenhoagronômico e naqualidade das sementes de soja RR. Planta Daninha, v. 30, n. 1, p. 139-146, 2012a.

ALBRECHT, L. P. et al. RR Soybean seed quality after application of glyphosate in different stages of development. R. Bras. Sementes, v. 34, n.3, p. 373-381, 2012 b.

ARREGUI, M. C.et al.Monitoring glyphosate residues in transgenic glyphosate-resistant soybean. PestManag.Sci., v. 60 , n. 2, p. 163-166, 2003.

BRASIL. Ministério da Agricultura. Padrões para produção e comercialização de sementes de soja. DOU, n. 243 de 20 de dez. 2005. Seção 1. p. 2.

BRASIL. Ministério da Agricultura, Pecuária e Abastecimento. Regras para análise de sementes.Brasília, DF: Secretaria de Defesa Agropecuária, 2009. 395 p.

DUKE, S. O. et al. Isoflavone, glyphosate, and aminomethylphosphonic acid levels in seeds of glyphosatetreated, glyphosateresistant soybean. J. Agric.

FoodChem.,v. 51, n. 1, p. 340-344, 2003.

EMPRESA BRASILEIRA DE PESQUISA AGROPECUÁRIA - EMBRAPA.Tecnologias de produção de soja- Paraná - 2007. Londrina, Embrapa Soja, 2006. 208 p. (Sistemas de Produção).

HENNING, A. A. Patologia de sementes. Londrina: Embrapa Soja, 1994. (Documentos, 90).

HOAGLAND, R. E. Effects of glyphosate on metabolismo f phenolic compounds: VI. Effects of glyphosate and glyphosate metabolites on phenylalanine ammonia-lyase activity, growth, emd protein, chlorophyll, and anthocyanin levels in soybean (Glycine max) seedling. Weed Sci., v. 28, n. 2, p. 393-400, 1980.

HUBER, D. M. What about glyphosate-induced manganese deficiency. Fluid J., Fall, p. 20-22, 2007.

JOHAL, G. S.; HUBER, D. M. Glyphosate effects on disease and disease resistance in plants. Eur. J. Agron., v. 31, n. 3, p. 144-152, 2009.

KEEN, N. T.; HOLLIDAY, M. J.; YOSHIKAWA, M. Effects of glyphosate on glyceollin production and the expression of resistance to Phytophthoramegasperma f. sp. glycinea in soybean. Phytopathology, v. 72, n. 11, p. 1467-1470, 1982.

KREMER, R. J.; MEANS, N. E.; KIM, S. Glyphosate affects soybean an root exudation and rhizosphere microorganims. Inter. J. Environ. Anal. Chem., v. 85, n. 15, p. 1165-1174, 2005.
LEE, T. T. Mode of action of glyphosate in relation to metabolismo findol-3-acetica acid. Physiol. Plant., v. 54, n. 3, p. 289-294, 1982.

LYDON, J.; DUKE, S. O. Pesticide effects on secondary metabolism of higher plants. Pest. Sci., v. 25, n. 4, p. 361-373, 1989.

MARCOS FILHO, J. Fisiologia de sementes de plantas cultivadas. Piracicaba: Fealq, 2005. 495 p.

NEUMANN, G. et al. Relevanceofglyphosate transfer to non-target via the rhizosphere. J. Plant Disease Protec., v. 20, p. 963-969, 2006. (Special Issue)

REDDY, K. N.; RIMANDO, A. M.; DUKE, S. O. Aminomethylphosphonic acid, a metabolite of glyphosate, causes injury in glyphosate-treated, glyphosate-resistant soybean. J. Agric. FoodChem., v. 52, n. 16, p. 5139-5143, 2004.

RIZZARDI, M. A. et al. Ação de herbicidas sobre mecanismos de defesa das plantas aos patógenos. Ci. Rural, v. 33, n. 5, p. 957-965, 2003.

SANTOS, J. B. et al. Efeitos de diferentes formulaçõescomerciais de glyphosate sobre estirpes de Bradyrhizobium.Planta Daninha, v. 22, n. 2, p. 293-299, 2004.

SANTOS, J. B. et al. Efeito de formulaçõesnaabsorção e translocação do glyphosateem soja transgênica.

Planta Daninha, v. 25, n. 2, p. 381-388, 2007.

TAIZ, L.; ZEIGER, E. Fisiologia vegetal. 4.ed. Porto Alegre: Artmed, 2009. 848 p.

ZABLOTOWICZ, R. M.; REDDY, K. N. Impact of glyphosate on the Bradyrhizobiumjaponicumsymbiosis with glyphosate-resistant transgenic soybean: A minireview. J. Environ. Quality, v. 33, n. 3, p. 825-831, 2004.

ZOBIOLE, L. H. S. et al. Effect of glyphosate on symbiotic N2 fixation and nickel concentration in glyphosateresistant soybeans. Appl. Soil Ecol., v. 44, n. 2, p. 176-180, 2010a.

ZOBIOLE, L. H. S. et al. Water use efficiency and photosynthesis of glyphosate-resistant soybean as affected by glyphosate. Pestic. Biochem. Physiol., v. 97, n. 3, p. 182-193, 2010b.

ZOBIOLE, L. H. S. et al. Glyphosate affects lignin content and amino acid production in glyphosate-resistant soybean. Acta Physiol. Plant., v. 32, n. 5, p. 831-837, 2010 c.

ZOBIOLE, L. H. S. et al. Glyphosate reduces shoot concentrations of mineral nutrients in glyphosate-resistant soybeans. Plant Soil, v. 328, n. 1/2, p. 57-69, 2010d. 